\title{
The dilemma of instructional language in education: The case of Ghana
}

\author{
SAMUEL OPOKU APPIAH $^{1 *}$ (]) and ALFREDO ARDILA ${ }^{2}$
}

\author{
${ }^{1}$ Eötvös Loránd University (ELTE), Faculty of Primary and Pre-School Education, 40 Kiss János \\ altabornagy Street, H-1126, Budapest, Hungary \\ ${ }^{2}$ Albizu University, 2173 NW 99th Avenue, Miami, Florida, 33172, United States of America
}

\section{RESEARCH ARTICLE}

Received: November 30, 2020 • Accepted: April 12, 2021

(c) 2021 The Author(s)

\begin{abstract}
According to Victor Hugo (1802-1885), "He who opens a school door, closes a prison". This powerful statement demonstrates the importance of school in the development of a nation and the lives of individuals. It has been proven that the language used in early childhood education has an impact on the cognitive development and learning achievement of children in their educational arena.

Most countries in Africa are still discussing the language to be used as a medium of instruction in their educational system.

Ghana, which is known as a multilingual society with over 80 languages is not excluded from this controversy. The language policy of education in Ghana has had a complex history since the colonial era. The question of international schools in Ghana is critically examined; most of these schools do not teach any of the Ghanaian languages, but a foreign language.

Ghana, however, has been a strong advocate of the so-called African personality and the use of English as the medium of instruction is in overt opposition to this ideology. The argument about which language to be used as a medium of instruction in Ghanaian Schools has been going on for a long time without coming to a specific conclusion.
\end{abstract}

\section{KEYWORDS}

school language, Ghana, English, multilingualism, early childhood education

\footnotetext{
*Corresponding author. E-mail: Agyapoku27@gmail.com
} 


\section{INTRODUCTION}

The majority of the 54 African countries until recently were European colonies, and the language of the colonizer country quite frequently was used as the lingua franca (Gann, Duignan, \& Turner, 1969; Obondo, 1997). Schools and universities mostly used the colonizer language, usually, English, French, and Portuguese, and in few cases, Spanish, Italian, and German. When these countries became independent, in most cases during the second half of the $20^{\text {th }}$ century, colonizer language generally was maintained as official or co-official language.

The educational system in the majority of the countries maintained the European language as the instructional language. That situation resulted in a contradictory and ambiguous situation: children were schooled in an insufficiently known language, not used in their social community. On the other hand, teachers were required to teach in an insufficiently known foreign language.

From our point of view destroying any nation does not require the use of atomic bombs or the use of long range missiles but it's only requires lowering the quality of education because if the school system is not well equipped and maintained it will have a negative impact on such nation.

Patient will die at the hands of such doctors. Buildings will collapse at the hands of such engineers. Money will lost at hands of such economists and accountants. Humanity will die at hands of such scholars and Justice will lost at hands of such judges.

The collapse of education is the collapse of a nation. This shows how important the school is. And hence it must be seen as the most priority of every nation and the language of instruction use in the early childhood education must be critically examined in any educational system because the foundation of everything is the most important. The negative consequences of this situation are obvious: learning was low and academic insufficient (Bodomo, 1996; Mohanty, 2017, pp. 261-280).

\section{THE QUESTION OF SCHOOL LANGUAGE IN GHANA}

Ghana is a former colony of the United Kingdom, becoming independent in 1957 (Gocking, 2005). Close to 80 different languages are spoken, but English is the language of education, the government, and the business activities. English has become the language of power and prestige and those who are competent in it maintain a higher social position. It is frequently perceived that the level of English determines the social success and academic achievement, regardless that English is a second language (Opoku-Amankwa, 2009; Owu-Ewie, 2006).

A similar situation is observed in many African countries. If you speak English well, you will enjoy a special place in society and higher esteem because it is perceived that the level of your English language determines the level of your intellectual ability (Saah, 1986).

Passing a Basic Education Certificate Examination (BECE) is required to enter high school. However, this exam is taken in English. Because of this language barrier, many students fail. Quite frequently, students do not have the sufficient proficiency in English to write and pass this national examination to guarantee their progress to the next level of their education ladder (Davis \& Agbenyega, 2012).

A significant diversity of languages are spoken in Ghana. According to Ethnologue (2020), there are 79 different languages (belonging to the Proto Tano, and Volta-Congo language 
groups). These languages are distributed over a total population of approximately 29 million people spread over ten geographic/administrative-regions occupying $239,567 \mathrm{~km}^{2}$. These languages tend to be closely associated with ethnic groups (Dakubu, 2015; Ghana Institute of Language, 2020).

Consequently, one might easily assume that there are as many ethnic groups as there are languages. However, a close examination reveals, what is usually described as a language group, typically consists of a cluster of socio-culturally and linguistically related ethnic groups who do not see themselves as internally homogeneous.

For example, Akan, the largest ethnolinguistic group in Ghana, is constituted by a cluster of ethnic and sub-ethnic groups who speak different but largely mutually intelligible dialects of the Akan/Twi language. Akan ethnic group alone constitutes $49.1 \%$ of the national Ghana population, Mole-Dagbani 16.5\%, Ewe 12.7\%; Ga- Adangbe 8\%, and Guan 4.4\% (Ghana Statistical Services, 2002). While $90.7 \%$ of Ghana's population is constituted by only 5 ethnic language groups, the remaining ethnolinguistic groups constitute only $9.3 \%$ of Ghana's population. The number of native English speakers in Ghana is close to zero.

Ghana is a highly multilingual country with no national language (Boahene-Agbo, 1985). As a result, language choice is determined by social factors, such as the background of the interlocutors involved in the communication, or the specific region where you are situated. English, Akan, and Ewe have emerged as important lingua francas and different forms of diglossia have developed in Ghana (Obeng, 1997). For instance, there is a Ghanaian English dialect that represents an English creole. However, only English is the official language, although there are nine government's-sponsored languages supported by the Bureau of Ghana Languages.

\section{THE HISTORY OF LANGUAGE POLICIES IN GHANAIAN SCHOOLS}

There exists a language controversy concerning which language should be used as a medium of instruction in African schools, especially at the lower basic level. back to the so-called "castle schools" and missionary era. Before formal education was introduced in Africa, traditional education was conducted in the indigenous languages. With the inception of formal education and the subsequent use of English or other European languages as the medium of instruction in Sub-Saharan Africa, the indigenous languages were seen as "inadequate" as teaching media (Bamgbose and Bamgbose, 2000). Bilingual education commenced with the inception of formal education in the castle schools and later was continued with the Christian missionaries. This period is the pre-colonial period. The languages used were those of the "metropolitan" country (the "metropolitan languages"): Portuguese, Dutch, French, Danish, English, etc.

The situation, however, changed with the arrival of the missionaries, who resorted to the development of the local languages in both their educational and proselytizing efforts (Graham, 2013). The language policies during this period were as varied as they were independent (Andoh-Kumi, 1994). During this period, a systematic pattern began to emerge with regard to both education and language use. The first legislation discussing the use of a Ghanaian language in education was promulgated during the early $20^{\text {th }}$ century (MacWilliam, 1969; Graham, 2013). It was determined that Ghanaian languages were to be used as the medium of instruction only at the lower primary level, with English used thereafter. 
The policy was reversed and became unstable when the administration of the country came under the jurisdiction of indigenous Ghanaians in 1957. Since then, the use of a Ghanaian language as the medium of instruction at the lower primary level has had a checkered history. From 1925 to 1951, Ghanaian languages were used as medium of instruction for the first three years, but later, between 1951 and 1956, those languages were only used for the first year. From 1957 to 1966 Ghanaian languages were not used at all; from 1967 to 1969 they were used only for the first year, and between 1970 and 1974 Ghanaian languages were used for the first three years and where possible beyond (to the sixth year). From 1974 to 2002, Ghanaian languages were again used for the first three years.

A Ghanaian language in this case is understood as the language of the locality including one of the following: Akan (Fante and Twi), Nzema, Ga, Ga-Adangbe, Ewe, Gonja, Kasem, Dagbani, and Dagaare.

In January 2001, the Director General of the Ghana Education Service (GES) signed a letter that sought to remind its officials, teacher associations and all heads of Basic Schools in the country about the then existing language policy originally announced in 1971. Essentially, this Policy states that, instruction at the Lower Primary Level (Primary 1-3) will be conducted in the pupil's mother tongue, or in the major Ghanaian Language of the local area, while English will be studied as one of the subjects offered at the Lower Primary Level. From Primary 4 onwards, class instruction will be conducted in English; and the Ghanaian Language will then be studied as one of the subjects offered.

The Director General rationalized the policy as follows: The fundamental philosophy underlying the Ghanaian Language Policy in our schools is to enable the individual to acquire a sense of cultural identity and make him/her literate in his/her own mother tongue. Another essential factor is that basic literacy in one's mother tongue or the local language enhances the child's ability to transfer and apply acquired learning skills in the local language to proficiency in subsequently learning English and other languages (Signed by the Director General of GES, Jan. 2001).

However, within 17 months of the circulation of this reminder, a policy change was declared by the Minster of Education, which compelled the GES Director General to send another circular to inform the same recipients that: (a) English should replace vernacular as the medium of instruction in the first three years of Primary schooling. (b) Every Ghanaian child must study one local language from Primary One level up to the Senior Secondary School Level. (c) Students should be encouraged to study the French Language.

In 1987, the People's National Democratic Congress (PNDC) government, under pressure from the World Bank and the International Monetary Fund, introduced a major educational reform, which reduced basic and secondary education from 15 to 12 years and increased university education from three to four years. Instead of focusing mainly on academic content, the reform introduced technical and vocational skills training in the Basic School curriculum (Osei, 2004).

Though the reform might have been well intended, it was perceived that the government had rushed to implement it without prior adequate preparation, including the training of teachers, provision of school infrastructure, supply of books and equipment and education of the Ghana population. Consequently, when the majority of the first batch of graduates from the new school system failed their final examinations, criticism of the reform intensified, and suggestions were made for a return to the former system. 
Within a period of three and a half years, January 2001 to August 2004, heads of Basic Schools received three circulars stating different language policies they were expected to implement in P1 - 3, i.e. (a) the sole use of local language in teaching, (b) the sole use of English, and (c) the use of both local language and English.

The presentation above gives only a glimpse of the general lack of continuity and consistency, a major problem that has dogged language-in-education policy since the inception of formal education in Ghana. Since the announcement of the change of policy, the debate over the language of education has picked up momentum from academics, politicians, educators, educational planners, traditional rulers, and the general populace.

Ghana has been a strong advocate of the African personality since Nkrumah's era. Nkrumah was the first Prime Minister and President of Ghana between 1957 and 1960. The promulgation of the use of English as the medium of instruction in education and the abandoning of her indigenous languages in education is in overt opposition to this ideology. Unlike most francophone countries, which had French forced on them as medium of instruction through the Brazzaville Conference of 1944 and made the use of local languages in schools forbidden (Djite, 2000), Ghana England laid a solid foundation for the use of the indigenous languages as of instruction at least at the lower primary level. For example, Cote d'Ivoire prior to independence in 1960 entered into agreement with France to maintain the cultural and linguistic policies of their colonizers (Djite, 2000).

Ghana's current Education policy includes two years of Kindergarten (KG) as part of its commitment to Free and Compulsory Basic Education and places it ahead of the curve compared to other countries in sub-Saharan African countries. Recognizing the benefits in the past two decades, Ghana, through Ministry of Education and Ghana Education Services, has registered increased national efforts to equitably expand KG services, especially for the most vulnerable and disadvantaged children (Avoke \& Hayford, 2017). Since the year 2,000, the Ministry of Education and Ghana Education Services has actively worked towards universal access to basic education.

\section{THE MERITS OF MOTHER TONGUE IN EARLY CHILDHOOD EDUCATION}

There has been so many research findings which has proven that having a solid mother tongue in early childhood education leads to much better comprehension of the curriculum as well as more optimistic attitude towards school, so it important that children maintain their native language when they begin schooling in diverse language.

In the process of bringing together all the ideas and perceptions about the language of instruction in Ghanaian schools, it is very crucial to shed more light on the merits of mother tongue education about this major national debate which has been going on for years now and which became more serious concerning the statement made by the former minister of education Professor Jane Naana Opoku-Agyemang, Minister of Education (former Vice Chancellor of University of Cape Coast) during a forum held on 16th October, 2015 at the University of Ghana.

The issue again gained headline prominence in Ghanaian media, notably Joy FM, a popular radio station in Accra. On this station, as well as on their online blog My Joy Online, there have been extensive discussions of educational language policy. The Minister in this instance has 
opened up another opportunity for debate and has also provided reasons for change in language of instruction.

The Minister stated that "very soon Ghana would change the use of English as medium of instruction in school". The Minister is of the view that Ghanaian students struggle in school because they are taught in a language they don't understand. This, according to her, has affected the development of the country. She cited Korea as an example of the countries that used to be economically at the same level as Ghana, but which have advanced considerably due to the use of local languages in educating their people. Conversely, Korea has in recent years focused on huge investment in the development of English in the country. The Minister further indicated that "in order for Africa to end poverty, it must focus on quality, relevant education delivered in the right medium" (Essel, 2015).

She is of the view that once the country removes English as the medium of instruction, "there would be change." Change here, to my understanding, refers to economic development leading to prosperity. The Minister's statement received support from a number of educationists. For instance, during another radio discussion, Mr. Michael Nsowah (former Director General of Ghana Education Service) (GES), supported the Minister's decision by indicating that "research has proven that children are able to learn faster when they are taught in language they play with" (My Joy Online, 2015). The basis for arguing for a new language policy in Ghana by the Minister has not only received support, but has encouraged other educationists to add their voices.

The right type of language to use as a medium of instruction in schools has been a thorny issue to contend with for some time now. Ghana, like many African countries, has not been spared this challenge of choice. In fact, it has become a major matter of concern to many of us. Findings say children who are taught in their mother tongues tend to grasp educational concepts and principles faster and easier than they do when taught in other languages. It has also been established that the use of mother tongue as a medium of instruction in early grades of education sets the tone for effective acquisition of any other language.

Language policy on education in Ghana, by way of history, has undergone several metamorphoses. A cursory look at things has shown that our nation did pursue a Dual Language Policy before 1925. The Wesleyan Missionaries, who settled along the western coast of then Gold Coast, used English Language as a medium of instruction in schools while Ga, Ewe and Twi were used along the eastern coast and inland parts of the country by the Bremen and Basel Missionaries. These local languages were developed and effectively used by the Missionaries. Osofu-Appiah (1976) identifies that, "as far back as 1872 Arithmetic was taught wholly in Twi and Ewe and the Twi and Ewe Grammars and Dictionaries were among the best in the world of scholarship.

However, most people also share the views that since Ghana is a multilingual country and there is no one common language to be used as a "sole" language of instruction in schools, It will be a mess for this to be possible. Adding more evidence to support their opinion, they also believe that proposal "language in question" will be an advantage to some ethnic group and disadvantage to others.

Moreover, this argument has already been addressed in Ghana. It is an indisputable truth that the Bremen and the Basel missionaries were able to use the local language in their education "way back" in 1872 and it was successfully compared to their Wesleyan counterpart who used English. This is not something new to emerge in the Ghana education system, most people were against this policy because they think English language is internationally recognized and has so many advantages than the use of the local language. 


\section{CONCLUSION}

Instructional language has been a long-lasting question in multilingual countries. This question acquires a special perspective in most African countries of which Ghana is not excluded. According to researchers there is a link between a child's cognitive development and their mother tongue. Children who develop skills in their native language and other languages grow up to have an in-depth understanding of how to express themselves, interacting with their peers, making it easier in their communication and the use of language as a whole.

To get an in-depth knowledge about the positives and negatives sides of using a native language as a medium of instruction we try to do a thorough research about the negative effects of teaching students in their native language and to our surprise there was no research that gave a vivid negative reasons of learning in your own native language but there are many numerous reason to study a second language apart from your native language.

In conclusion, we draw the curtains down by emphasizing that for effective, efficient and "problem solving" education system in Ghana, the use of the mother tongue as instructional language in early childhood education will be a better option for children and the development of Ghana as whole.

Education is the "key to success" but if children are taught in a language they are not comfortable and competence in it, the "key to success" divert to the "key to stress". Nelson Mandela once said, "If you talk to a man in a language he understands, it goes into his head. But If you talk to him in his native language, it goes into his heart."

\section{ABOUT THE AUTHORS}

Samuel Opoku Appiah is a Ghanaian student who holds a bachelor degree in Social Science (History and Political Science) from the University For Development Studies in Ghana, and masters degree in "Psycholinguistics of Intercultural Communication", from I.M. Sechenov First Moscow State Medical University (Moscow, Russia). Currently in Eötvös Loránd University (ELTE) Budapest, Hungary. Research interests are in Cross-Cultural Psychology, Intercultural Communication, Linguistics and Development Studies.

Alfredo Ardila, PhD, was a Professor at the Institute of Linguistics and Intercultural Communication, I.M. Sechenov First Moscow State Medical University (Moscow, Russia); Distinguished Professor at Albizu University (Miami, USA), who passed away January 2021 after a short illness.

\section{ACKNOWLEDGEMENT}

Immeasurable appreciation goes to the King of Glory (God) for the wisdom he bestowed upon me, the strength, the peace of mind and the good health in order to make this paper reality. I cannot express enough thanks to my co-author, mentor and my master's thesis scientific research supervisor, Distinguished Professor Alfredo Ardila, $\mathrm{PhD}$, who was a Professor at the Institute of Linguistics and Intercultural Communication, I.M. Sechenov First Moscow State 
Medical University (Moscow, Russia); Distinguished Professor at Albizu University (Miami, USA) who sadly passed away in January 2021.

Mr. Timothy Lehman of Horvath Mihaly Gimnazium, Szentes for reading through the whole paper and correcting all the grammatical errors. My mother Jemamah Kessewah Poku, late grandfather Mr. PCK Poku and late uncle Mr. Solomon Kwadwo Poku Boadu for supporting and encouraging me throughout my education to this level.

\section{REFERENCES}

Andoh-Kumi, K. (1994). Topics in Ghanaian language education. Unpublished master's thesis). Legon, Ghana: University of Ghana.

Anyidoho, A. (2004). English only as medium of instruction in primary 1-3. Legon Journal of the Humanities, 15, 81-97.

Anyidoho, A., \& Kropp Dakubu, M. E. (2008). Indigenous languages, English and an emerging national identity. In A. Simpson (Ed.), Language and National Identity in Africa. Oxford: Oxford University Press.

Avoke, S. K., \& Hayford, S. K. (2017). Republic of Ghana (p. 352). The Praeger International Handbook of Special Education. [3 volumes].

Bamgbose, A., \& Bamgbose, A. (2000). Language and exclusion: The consequences of language policies in Africa (Vol. 12). LIT Verlag Münster.

Boahene-Agbo, K. (1985). The republic of Ghana: An example of African multilingualism: Bilingual communities: Linguistic minorities and their verbal repertoires. Annual Review of Applied Linguistics, 6, 66-77.

Bodomo, A. B. (1996). On language and development in Africa: The case of Ghana. Nordic Journal of African Studies, 5(2), 31-51.

Dakubu, M. E. K. (2015). The languages of Ghana. Routledge.

Davis, E., \& Agbenyega, J. S. (2012). Language policy and instructional practice dichotomy: The case of primary schools in Ghana. International Journal of Educational Research, 53, 341-347.

Djite, P. G. (2000). Language planning in Côte d'Ivoire. Current Issues in Language Planning, 1(1), 11-46.

Essel, I. (2015, October 16). Ghana to change English as medium of instruction. http://www.myjoyonline. com/news/2015/October-16th/ghana-to-change- english-as-medium-of-instruction.php.

Ethnologue (2020). https://www.ethnologue.com/ [Accessed 02 Feb 2020].

Gann, L. H., Duignan P., \& Turner, V. W. (Eds), (1969). Colonialism in Africa 1870-1960 (Vol. 4). CUP Archive. Ghana Institute of Languages (2020). http://gil.edu.gh/Retrived020/02/2020〉.

Ghana Statistical Service (2002). http://www2.statsghana.gov.gh/nada/index.php/catalog? \&page=4 [Accessed 05 Mar 2019].

Gocking, R. (2005). The history of Ghana. Greenwood publishing group.

Graham, C. K. (2013). The history of education in Ghana: From the earliest times to the declaration of independence. Routledge.

MacWilliam, H. O. A. (1969). The development of education in Ghana. Accra, Ghana: Longmans.

Mohanty, A. (2017). Multilingualism, education, English and development: Whose development. Multilingualisms and Development.

Obeng, S. G. (1997). An analysis of the linguistic situation in Ghana. African Languages and Cultures, 10(1), 63-81. 
Obondo, M. A. (1997). Bilingual education in Africa: An overview. Bilingual education (pp. 25-32). Dordrecht: Springer.

Opoku-Amankwa, K. (2009). English-only language-in-education policy in multilingual classrooms in Ghana. Language, Culture and Curriculum, 22(2), 121-135.

Osei, G. M. (2004). The 1987 junior secondary-school reform in Ghana: Vocational or pre-vocational in nature? International Review of Education, 50(5-6), 425-446.

Osofu-Appiah, L. H. (1976). Sophocles Antigone. Waterville: Accra.

Owu-Ewie, C. (2006). The language policy of education in Ghana: A critical look at the English-only Language Policy of education. In Selected proceedings of the 35th annual conference on African linguistics., Somerville, MA (pp. 76-85). Cascadilla Proceedings Project.

Saah, K. K. (1986). Language use and attitudes in Ghana. Anthropological Linguistics, 367-377.

The Bureau of Ghana Languages-BGL. http://www.bgl.gov.gh/language-section.php [Accessed 04 Jul 2019].

Open Access. This is an open-access article distributed under the terms of the Creative Commons Attribution 4.0 International License (https://creativecommons.org/licenses/by/4.0/), which permits unrestricted use, distribution, and reproduction in any medium, provided the original author and source are credited, a link to the CC License is provided, and changes - if any - are indicated. (SID_1) 